Int. J. Dev. Biol. 65: 475-485 (2021)

https://doi.org/10.1387/ijdb.210041rs

\title{
Methods to generate and evaluate zebrafish models of human kidney diseases
}

\author{
SANA FATMA ${ }^{1,2}$, USHARANI NAYAK ${ }^{1,3}$ and RAJEEB K. SWAIN ${ }^{*, 1}$ \\ ${ }^{1}$ Institute of Life Sciences, Nalco Square, Chandrasekharpur, Bhubaneswar, ${ }^{2}$ Manipal Academy of Higher Education, \\ Manipal and ${ }^{3}$ Regional Centre for Biotechnology, Faridabad, India
}

\begin{abstract}
Kidney-related disorders affect millions of people worldwide. A survey of chronic kidney disease (CKD) patients showed that the burden of kidney diseases is increasing every year. The global burden of disease (GBD) study 2017 ranked CKD as the $12^{\text {th }}$ leading cause of deaths worldwide. Hence, identification of the causes of kidney diseases, development of accurate diagnostic methods and novel therapeutics is highly relevant. Model organisms that faithfully recapitulate human diseases play important roles in understanding the disease process and provide valuable ground to find their cure. Zebrafish is an excellent model to study the development, pathophysiology and molecular aspects of human kidney diseases. In this review, we summarize various genetic and experimental manipulations that can be carried out in zebrafish to better understand the pathophysiology of human kidney diseases. We suggest that these methods will be helpful in the development of potential therapies to treat kidney diseases.
\end{abstract}

KEY WORDS: CKD, AKI, zebrafish model of human kidney diseases, pronephros, renal pathology

\section{Introduction}

Kidney is one of the vital organs in vertebrates that removes waste products and maintains $\mathrm{pH}$, ion and metabolite concentration of blood within physiological range. Kidney secretes erythropoietin that regulates red blood cell production and activates vitamin D which helps bones to absorb calcium. There are about a million nephrons in each human kidney, which are the structural and functional unit of this organ. Consequently, defects in nephrons affect kidney structure and functions. Dysfunction of kidney can occur because of genetic mutations, infections, injury, medicines or exposure to toxic compounds in the environment. Chronic diseases like diabetes, cardiovascular diseases and hypertension are major contributors to kidney disease burden (Levey et al., 2010). Impaired kidney function increases the risk of complications in other organ systems as well (Thomas et al., 2008). The common types of kidney diseases and their causes are outlined in Table 1.

\section{Kidney diseases}

Kidney diseases contribute to a significant fraction of the disease burden globally. Around 750 million people worldwide are affected with kidney related disorders (Crews et al., 2019). CKD is most common among them with global prevalence of $13.4 \%$ (Hill et al.,
2016). The GBD study 2010 ranked CKD as the $18^{\text {th }}$ leading cause of death worldwide, which had jumped to $12^{\text {th }}$ by 2017 for causing maximum number of deaths globally (Jha et al., 2013; Carney, 2020). According to the GBD study 2017, about 697.5 million cases of CKD were reported worldwide, among which 1.2 million people had died. The number of deaths due to CKD is estimated to rise to 4 million by 2040 in the worst-case scenario (Foreman et al., 2018). One third of CKD patients live in two countries, China and India (Bikbov et al., 2020). The status of CKD among Indian population is unclear due to the lack of accurate data collection systems. About 115 million cases of CKD were reported in India in 2017 (Bikbov et al., 2020). The most common diseases in Indian population are diabetes and hypertension (Geldsetzer et al., 2018). As per the Indian Council of Medical Research (ICMR) report, the prevalence of diabetes and hypertension among the urban adult population is $28 \%$ and $21.4 \%$ respectively (Varma, 2015). Between $40 \%$ to $60 \%$ of CKD cases occur because of these complications and their number is increasing rapidly (Rajapurkar et al., 2012). The International Society of Nephrology's kidney disease data center reported a $16.8 \%$ prevalence of CDK among Indian population (Ene-lordache et al., 2016). The causes of CKD vary throughout India. Andhra Pradesh, Odisha and Goa reported high levels of CKD of an unknown etiology known as chronic interstitial nephropathy (Varughese and Abraham, 2018). As the number of CKD patients

\footnotetext{
*Address correspondence to: Rajeeb K. Swain. Institute of Life Sciences, Nalco Square, Chandrasekharpur, Bhubaneswar - 751023, India.

E-mail: rkswain@ils.res.in - iD https://orcid.org/0000-0003-4815-8221
} 


\section{TABLE 1}

\section{DIFFERENT TYPES OF KIDNEY DISEASES AND THEIR CAUSES}

\begin{tabular}{|c|c|}
\hline Kidney diseases & Causes \\
\hline Acute kidney diseases & $\begin{array}{l}\text { Shock, surgery, medications, infections or impaired cardiac } \\
\text { function which causes injury to nephron epithelial cells. }\end{array}$ \\
\hline Chronic kidney diseases & $\begin{array}{l}\text { Complications like diabetes, high blood pressure, anemia, } \\
\text { glomerulonephritis (inflammation in glomerulus), lupus and } \\
\text { other autoimmune diseases, urinary tract infections, poly- } \\
\text { cystic kidney diseases, kidney stones or renal tumors which } \\
\text { disrupt kidney functions. }\end{array}$ \\
\hline $\begin{array}{l}\text { Renal stones } \\
\text { (Nephrolithiasis) }\end{array}$ & $\begin{array}{l}\text { Impaired kidney functions increase the levels of cystine, } \\
\text { oxalate, uric acid or calcium in the urine, which form clumps. }\end{array}$ \\
\hline Nephrotic syndrome & $\begin{array}{l}\text { Genetic mutations, medications or other disease complica- } \\
\text { tions can damage the blood vessels present in the glomeru- } \\
\text { lus and cause loss of proteins through the urine. }\end{array}$ \\
\hline Urinary tract infection & $\begin{array}{l}\text { An infection in any part of the urinary system, which com- } \\
\text { prises the glomerulus, bladder, ureters and urethra. }\end{array}$ \\
\hline $\begin{array}{l}\text { Congenital kidney diseases: } \\
\text { Diureter, horseshoe kidney, renal } \\
\text { dysplasia, ciliopathies, ADPKD, } \\
\text { PKD, MCK, etc. }\end{array}$ & Genetic mutations. \\
\hline
\end{tabular}

is increasing worldwide at an alarming rate, there is an urgent need to carry out a thorough analysis of the root causes of common kidney diseases in order to find better ways for their prevention and cure. Model organisms which can mimic human physiology and diseased conditions can provide great avenues in addressing the above problems. Zebrafish has become a useful model to study development and diseases, and provides promising ways to identify new therapeutic targets and drugs. In this review, we have discussed various methods to recapitulate human kidney diseases in zebrafish and how these models can be used to understand disease pathogenicity and its underlying molecular mechanisms. This may result in the generation of novel therapeutic approaches for management and cure of kidney diseases.

\section{Similarities between human and zebrafish kidney}

The kidney development in mammals is unique as it takes place through three distinct structures during embryogenesis: pronephros, mesonephros and metanephros. The first two structures are transient in mammals and only the metanephros persists throughout the life (Smyth et al., 2017; Jain, 2014). Pronephros is the functional kidney during embryonic development in lower vertebrates like amphibians and fishes, which is replaced by mesonephros as the functional kidney at later stages (Tahara et al., 1993; Diep et al., 2015). Table 2 describes the time duration of different forms of kidney in human, mice, Xenopus and zebrafish.

Although the overall complexity of kidney increases as we move towards the higher forms, nephrons are the structural and functional units of all types of kidneys. Each nephron has three parts: renal corpuscle to filter blood, tubule to absorb and secrete solutes, and collecting duct to collect unwanted wastes for excretion. The tubular epithelium is patterned into different segments to carry out specific functions. Nephrons from all forms of kidney possess a similar segmentation pattern (Desgrange and Cereghini, 2015). The segmental organization of nephron of zebrafish pronephros and mesonephros is similar to mammalian metanephros, as shown in Fig. 1. The zebrafish pronephric tubule is divided into proximal convoluted tubule (PCT), proximal straight tubule (PST), and distal early (DE) and distal late (DL) tubules, which are analogous to the segmentation pattern of mammalian metanephric nephrons. Zebrafish has an endocrine gland named corpuscles of Stannius (CS), which maintains calcium homeostasis (Krishnamurthy, 1976). The CS is formed by transdifferentiation of renal epithelial cells in between DE and DL segments, which gradually separate from the tubule and form the paired CS gland that is positioned retroperitoneally at the surface of the kidney in adult fish (Roberts and Ellis, 2012; Naylor et al., 2018). One of the major difference between zebrafish and mammalian nephron is the lack of loop of Henle in zebrafish, which acts as countercurrent multiplier to generate medullary osmotic gradient for water conservation. This segment does not have any utility in zebrafish as it is a fresh water fish (Elmonem et al., 2018). Each segment possesses distinct cell types and segment specific gene expressions, which are conserved among vertebrates (Verlander, 1998; Desgrange and Cereghini, 2015). All kidney types follow similar pathways of development. The following four stages are successively involved in nephron development; $\mathrm{A}$ : induction of intermediate mesoderm to form renal primordium, B: epithelialization and growth of nephric duct, C: patterning of nephron into specialized segments, and D: vascularization of nephron for blood filtration (Drummond, 2003).

\section{Methods to generate zebrafish models of human kidney diseases}

Zebrafish possess one pair of pronephros which start to form after 12 hours post fertilization (hpf) and becomes fully functional by $48 \mathrm{hpf}$. Availability of whole genome sequence, $71 \%$ human genes having at least one zebrafish orthologue, ease of handling,

TABLE 2

\section{THE DIFFERENT FORMS OF KIDNEY AND THEIR TIME DURATION IN HUMAN, MICE, XENOPUS AND ZEBRAFISH}

\begin{tabular}{|c|c|c|c|c|}
\hline Different form of kidney & Human & Mice & Xenopus & Zebrafish \\
\hline Pronephros & $\begin{array}{l}\text { Forms by the 22nd day and disap- } \\
\text { pears by the } 4 \text { th week of gestation } \\
6 \text { to } 10 \text { pairs of tubules }\end{array}$ & $\begin{array}{l}\text { Begins to form at E8 } \\
3 \text { pairs of tubules }\end{array}$ & $\begin{array}{l}\text { Begins to form from stage } 12.5 \text {, } \\
\text { becomes functional by stage } 36 \text { and } \\
\text { disappears by stage } 64 \\
3 \text { pairs of tubules }\end{array}$ & $\begin{array}{l}\text { Development starts at } 12 \mathrm{hpf} \text { and becomes } \\
\text { functional by } 48 \mathrm{hpf} \\
\text { Single pair of tubules }\end{array}$ \\
\hline Mesonephros & $\begin{array}{l}\text { Begins to form around the 25th day, } \\
\text { remains present up to the 8th week } \\
\text { of gestation and gradually degene- } \\
\text { rates thereafter } \\
30-40 \text { mesonephric tubules }\end{array}$ & $\begin{array}{l}\text { Begins to form from E9, degeneration } \\
\text { starts at } E 14.5 \text { and all tubules disappear } \\
\text { within } 24 \mathrm{hr} \\
18 \text { pairs of tubules }\end{array}$ & $\begin{array}{l}\text { Begins to form at stage } 39 \text {, takes } 5 \\
\text { days to become functional, } 39 \text { extra } \\
\text { days to reach its full size, and re- } \\
\text { mains functional throughout life } \\
\approx 1000 \text { pairs of tubules }\end{array}$ & $\begin{array}{l}\text { Begins to form from } 10 \mathrm{dpf} \text {, becomes functio- } \\
\text { nal by } \approx 14 \mathrm{dpf} \text { and continues to mature in later } \\
\text { stages of development } \\
\approx 300 \text { tubules }\end{array}$ \\
\hline Metanephros & $\begin{array}{l}\text { Starts developing from the } 5 \text { th week } \\
\text { and nephrogenesis is complete by } \\
\text { the } 36 \text { th week of gestation } \\
\approx 300,000-1 \text { million nephrons }\end{array}$ & $\begin{array}{l}\text { Starts developing from E10.5, and } \\
\text { nephrogenesis continues after birth for } \\
\text { two weeks } \\
\approx 12000 \text { nephrons }\end{array}$ & Not formed & Not formed \\
\hline
\end{tabular}




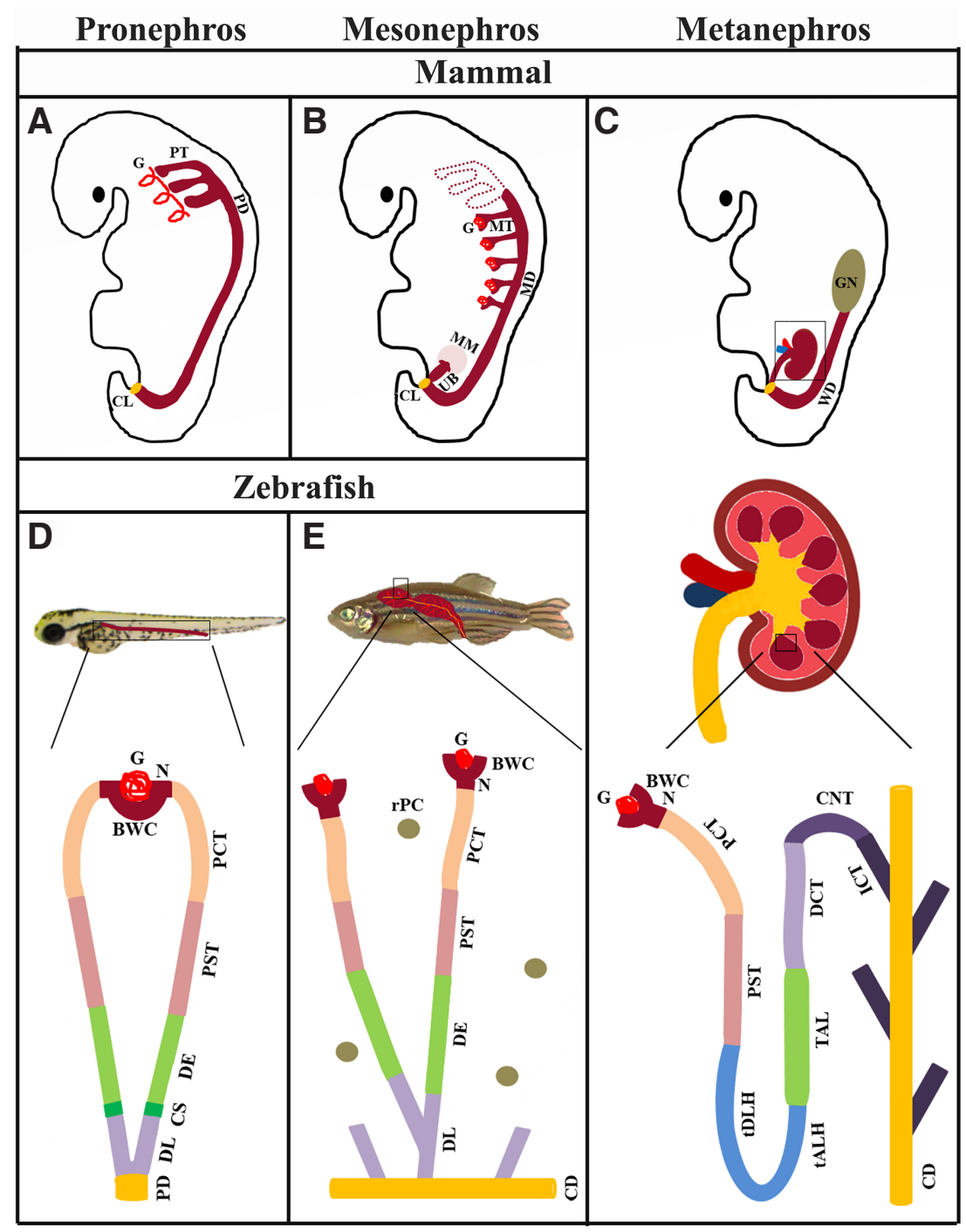

Fig. 1. Schematic representation of different forms of kidney present in mammals and zebrafish, and segmentation of the nephrons. (A) mammalian pronephros (B) mammalian mesonephros (C) mammalian metanephros (D) zebrafish pronephros and (E) zebrafish mesonephros. Pronephros and mesonephros are transient structures in mammals. A comparison of mammalian metanephric nephron segmentation (C) with zebrafish pronephros and mesonephric nephron (D\&E) shows a conserved segmentation pattern (the same colour represents equivalent segments), although loop of Henle is absent in zebrafish. BWC-Bowman's capsule, CD-collecting duct, $C L$ - cloaca, CNT - connecting tubule, CS - corpuscles of Stannius, DCT - distal convoluted tubule, DE-distal early, $D L$ - distal late, G - glomerulus, GN - gonad, ICT - initial collecting tubule, MD - mesonephric duct, MM - metanephric mesenchyme, MT-mesonephric tubule, N-neck, $P C T$ - proximal convoluted tubule, PD - pronephric duct, PST - proximal straight tubule, PT - pronephric tubule, $r P C$ - renal progenitor cell, tALH - thin ascending limb of the loop of Henle, TAL - thick ascending limb, $t D L H$ - thin descending limb of the loop of Henle, UB - uretic bud, WD - Wolffian duct.

males are treated with chemical mutagens such as ethyl methane sulphonate (EMS), ethyl nitrosourea (ENU) or physical mutagens like gamma radiation to generate a number of mutations in germ cells (Varshney and Burgess, 2014). The fish carrying mutations are then crossed with wild-type females to generate $\mathrm{F} 1$ fishes which contain unique alleles of generated mutation. F1 fishes are out-crossed to generate $\mathrm{F} 2$ carriers that are then in-crossed to obtain their homozygous mutants in $\mathrm{F} 3$ generation. The offspring having the desired phenotypes are then isolated and used for genetic mapping and sequencing to identify the mutated gene (Patton and Zon, 2001). Other variations of this screen, such as using haploid and homozygous diploid, can help to reduce the time and effort needed to identify the

transparent embryos, short generation time, efficient gene manipulation techniques, methods for transgenic fish generation and its rapid screening make zebrafish the most suitable model organism to study kidney abnormalities (Howe et al., 2013; Poureetezadi and Wingert, 2016). One of the crucial features of adult zebrafish is its ability to regenerate new nephrons by the process of neonephrogenesis in response to renal injury (Chambers and Wingert, 2016). Table 3 describes the comparisons between zebrafish and other common model organisms like mice and Xenopus. Genetic manipulations in zebrafish have shown that the novel genetic components of kidney development and function can be identified by using this model organism (Poureetezadi and Wingert, 2016). There are several methods to generate zebrafish models of human kidney diseases.

\section{Forward genetics}

The forward genetics screen is used to identify genes that are associated with phenotypes of interest (Lawson and Wolfe, 2011). Both chemical and insertional mutagenesis are used in forward genetics screens (Patton and Zon, 2001). Chemical mutagenesis is a three generation-based screening in which adult phenotype and the causative genetic mutation (discussed in detail by Patton and Zon, 2001). Transgenic reporter lines expressing fluorescent proteins in the organ of interest can be combined with conventional forward genetic screening to easily screen mutants of interest. An ENU based mutagenesis screen led to the identification of lightbulb (lib) mutant zebrafish which show morphological and nephron segmentation defects similar to retinoic acid (RA) deficient zebrafish embryos. It was found that lib mutants have $\mathrm{C}$ to $\mathrm{A}$ transition at nucleotide 174 of aldh1a2, which is predicted to synthesize a truncated protein of 58 amino acid length, thus abrogating aldh1a2 function and affecting synthesis of RA from retinaldehyde. Analysis of lib, neckless ( $n / s)$ mutant having point mutation in catalytic domain of aldh1a2 and DEAB (retinoic acid synthesis inhibitor) treated embryos revealed that the levels of RA modulate nephron segmentation by changing the spatial expression of segments specific transcription factors (Wingert and Davidson, 2011; Begemann et al., 2001; Mullins et al., 1994). Another mutant called zeppelin helped to identify brac2 as a regulator of podocyte development (Kroeger et al., 2017).

Insertional mutagenesis is a transposon or lenti-virus based method that is used to insert DNA randomly at different genomic loci, and this foreign DNA then helps to identify the mutated gene 
TABLE 3

A COMPARISON BETWEEN COMMONLY USED MODEL ORGANISMS: MICE, XENOPUS AND ZEBRAFISH.

\begin{tabular}{|c|c|c|c|}
\hline & Mice & Xenopus & Zebrafish \\
\hline Human genes that have at least one ortholog & $80 \%$ & - & $71 \%$ \\
\hline $\begin{array}{l}\text { Human disease associated genes that have at } \\
\text { least one ortholog }\end{array}$ & $90 \%$ & $79 \%$ & $84 \%$ \\
\hline Maintenance & High cost & Cost effective & Cost effective \\
\hline Development & In-utero & Ex-utero & Ex-utero \\
\hline Generation time & $6-8$ weeks of age & $\begin{array}{l}4 \text { months for } X \text {. tropicalis } \\
\text { and } 12 \text { months for } X \text {. laevis }\end{array}$ & 3 months \\
\hline Brood size & 6-12 pups/month & $2-3$ thousand, 3 to 4 times in a year & $\approx 200$ embryos/week \\
\hline $\begin{array}{l}\text { Time duration to generate homozygous } \\
\text { mutants/ transgenic lines }\end{array}$ & 5 months to 1 year & $1-2$ years & 9-10 months \\
\hline Mutant screening techniques & $\begin{array}{l}\text { Not easy, } \\
\text { some phenotypes take time to develop }\end{array}$ & $\begin{array}{l}\text { Easy phenotype-based screening, embryos are } \\
\text { opaque, in vivo imaging not at deep tissue level }\end{array}$ & $\begin{array}{l}\text { Easy phenotype-based screening, embryos are } \\
\text { transparent, in vivo imaging }\end{array}$ \\
\hline Drug screening & $\begin{array}{l}\text { Truly recapitulates human phenotype, low } \\
\text { throughput and expensive }\end{array}$ & High throughput and cost effective & High throughput and cost effective \\
\hline Difference with human metanephric nephron & Similar & $\begin{array}{l}\text { Glomus project in the body cavity not directly } \\
\text { connected with tubules }\end{array}$ & Loop of Henle is absent \\
\hline
\end{tabular}

(Amsterdam etal., 1999). The Hopkins'Laboratory at MIT performed an insertional mutagenesis screen in zebrafish embryos using a retroviral vector. They identified 12 genes which were associated with defective kidney phenotypes showing cysts in the glomerulartubular region, among which four were linked with cilia formation (Sun et al., 2004). The drawbacks of the forward genetics approach are that the screening process is cumbersome and time-consuming. However, the advances in new sequencing technology have made the forward genetics approach much more efficient.

\section{Gene knock-out using programmable nucleases}

One of the major advantages of using zebrafish as a modelorganism is the availability of efficient genome editing techniques such as CRISPR/Cas, TALEN and ZFN (Sertori et al., 2016). CRISPR (Clustered Regularly Interspaced Short Palindromic Repeat)/ Cas9 is the most versatile and commonly used genome editing technology in zebrafish. A chimera of CRISPR RNA (crRNA) and trans-activating crRNA (tracrRNA) is designed as a single guide RNA (sgRNA), which along with Cas9 protein/mRNA are injected into zebrafish embryos at one cell stage (Varshney et al., 2016). The sgRNA binds to the 20bp target DNA sequence adjacent to a protospacer adjacent motif (PAM) NGG sequence in the genome, Cas9 then generates a double strand cut in the target DNA sequence. This is then preferably repaired by non-homologous end joining, which being an error-prone repair mechanism results in the generation of random insertion/deletion (indel) leading to changes in the reading frame of coding sequence, and consequently abrogates the functions of the gene of interest. Advance methodologies have been developed in recent years to increase the efficacy of the CRISPR based genome editing technique (Liu et al., 2019). It is possible to delete a large fragment of DNA using two or more sgRNAs at a time (Kim and Zhang, 2020). It is also possible to simultaneously target multiple genes efficiently in a single zebrafish embryo (Shah et al., 2016). Many studies have been conducted to generate zebrafish mutants in order to recapitulate human kidney diseases by using CRISPR/Cas9 technology. CRISPR mediated knockout of ciliary membrane protein Arl13b resulted in generation of mutants which mimic the "Joubert syndrome" (Cantagrel et al., 2008). It is reported that mutations in human ELMO1 gene contribute to diabetic nephropathy. elmo1 mutant zebrafish exhibit phenotypes seen in hyperglycaemic embryos generated by knockdown of $p d x 1$ gene such as larger glomerulus, defective podocyte, shorter neck and hyperfiltration, thus highlighting the conserved function of this gene (Sharma et al., 2016). Mutant magi2a zebrafish exhibit steroid-resistant nephrotic syndrome which is also observed in people with mutations in MAGI2 (Jobst-Schwan et al., 2019). These observations highlight the suitability of zebrafish as an organism to model human kidney diseases.

Another method to generate zebrafish mutants is Transcription Activator-Like Effector Nucleases (TALEN) based genome editing. In this technique, the DNA binding domain TALE is made up of monomers, each monomer consisting of tandem repeats of 34 amino acid residues that bind to a particular nucleotide in the DNA sequence. These TALE sequences are derived from pathogenic bacteria Xanthomonas that alters the transcription of genes in host cells (Boch and Bonas, 2010). The TALEN targeting construct consists of a nuclear localization signal, the DNA binding domain and the Fokl nuclease domain at their carboxyl termini. TALEN work in pairs with their binding sites located on opposite strands of DNA separated by a 12 to 25 bp spacer sequence. The constructs bind to the target site in the nucleus and generate a double strand break, which is then repaired by a non-homologous end joining (Liu et al., 2014). The mutant zebrafish generated by CRIPSR or TALEN can activate genes that compensate for the loss-of-gene of interest, thus making it difficult to uncover the gene function (Rossi et al., 2015). However, it is possible to identify these compensatory genes by transcriptome analysis using next-generation sequencing (NGS) methods, which can help to identify the function of the gene of interest. Identification of genes and molecular pathways that compensate for the loss-of-function of a gene can be helpful in finding novel treatment methods for gene mutations that cause serious diseases (El-Brolosy and Stainier, 2017).

\section{Gene knock-down using morpholino antisense oligos}

Morpholinos are non-anionic oligonucleotides that are relatively stable as compared to its DNA or RNA oligomers (Summerton, 1999). The morpholino antisense oligo nucleotides bind to the mRNA of a target protein at its translation initiation site and block its translation. Another type of morpholino antisense oligos can target splicing junctions and block pre-mRNAsplicing (Summerton, 
1999). Morpholino-antisense oligo effect is transient and can be used to study the early developmental role of the genes of interest. Injection of morpholino-antisense oligo is done at the 1-4 cell stage of zebrafish embryos and its effect can be seen up to 3-5 days post fertilization (dpf) (Bill et al., 2009). Morpholino antisense oligo nucleotides often display off-target effects (Robu et al., 2007). Control experiments such as a rescue experiment should be performed by coinjecting morpholino along with mRNA that cannot be targeted by this antisense oligo to verify its specificity (Eisen and Smith, 2008). A photo activated morpholino has been developed, whose activity can be controlled in spatial and temporal manner by UV exposure (Tallafuss et al., 2012). Numerous studies have been carried out using morpholino antisense oligo mediated gene knock-down to understand human kidney diseases. For example, knock-down of nephrocystin-3 gene led to the formation of cysts and hydrocephaly in zebrafish embryos in a similar way to nephronophthisis type-3 disease (Zhou et al., 2010).

\section{Drug induced kidney damage model}

Aminoglycoside antibiotics generally used to treat many lifethreatening infections are known for their nephrotoxic and ototoxic effect (Mingeot-Leclercq and Tulkens, 1999). Gentamicin is a commonly used antibiotic that can induce acute kidney injury (AKI) in zebrafish. Gentamicin causes flattening of the brush border epithelium, loss of tubular epithelium, deformation of glomerulus structure, lysosomal phospholipidosis and accumulation of leukocytes or cell debris in the tubular lumen, which mimics gentamicin overdose in humans (Cianciolo Cosentino et al., 2010). Zebrafish has the ability to regenerate and replace damaged nephrons. Gentamicin insult can be used to study renal regeneration in zebrafish (Kamei et al., 2015). Gentamicin injury induces a regeneration response which triggers kidney stem cells to undergo the stages of specification, proliferation and differentiation to generate new nephrons. It takes around 14 to 21 days in adult fish to regenerate nephrons (Diep et al., 2011; McCampbell et al., 2015). Cisplatin, which is used as a chemotherapeutics drug to treat tumors, also has nephrotoxic effects, as observed in zebrafish (Hentschel et al., 2005). Etimicin is another aminoglycoside that can be used while mimicking low nephrotoxicity and ototoxicity in zebrafish embryos (Shao et al., 2020). Thus, AKI and renal regeneration can be studied in zebrafish with the help of these antibiotics.

\section{Mechanical injury to kidney}

The zebrafish pronephros can be physically injured using resection, stabbing or cryoinjury. Surgical injury can be performed by using fine tweezers to stab the desired area of the pronephros in order to create an AKI model. This technique was used to damage the pronephric duct close to the cloaca, which impaired fluid flow and led to cyst formation within 30 minutes (Kramer-Zucker, 2005). It was found that the reduction in fluid flow rate in pronephros generates back pressure at the fluid entry site, causing tubule luminal expansion and cyst formation. Another group of researchers made obstruction in the pronephric tubule at $50 \mathrm{hpf}$ or in mesonephric tubules of 12-month-old zebrafish by using tweezers to pinch off the area near the distal collecting tubules (Hellman et al., 2010). They discovered that the tubule scarring leads to an increase in cilia beating rate and an upregulation of the foxj1a transcription factor that regulates ciliogenic gene expression. This suggests that injury to pronephric tubules generates a cilia based mechanosensory signal to maintain nephron homeostasis.

\section{Laser induced kidney injury}

Laser mediated cell ablation is used as a tool to study renal injury and mimic AKI in zebrafish. Johnson et al., (2011) have described a method for laser mediated ablation followed by tracking of regenerating nephron. They injected $40 \mathrm{kDa}$ dextran-FITC in the trunk somites of zebrafish embryos at $48-55 \mathrm{hpf}$ to label the proximal tubule epithelial cells, which were then targeted for laser mediated ablation at $72 \mathrm{hpf}$. The ablated embryos were then reinjected with rhodamine dextran to trace the proximal tubule epithelial cells. They found that a fully developed proximal tubule was formed at the $7^{\text {th }}$ day following laser mediated ablation (Johnson et al., 2011). Another alternative is to use a kidney specific transgenic line to identify cells for laser mediated ablation and monitor behaviors of neighboring cells. A violet laser light of $405 \mathrm{~nm}$ wavelength was used to target pronephric tubule of $\mathrm{Tg}$ (atp 1a1a.4:GFP) zebrafish (Palmyre et al., 2014). As GFP excitation spectra lies in the range of blue to violet light, it absorbed $405 \mathrm{~nm}$ laser light, which acts as energy sink to potentially induce injury at the target epithelial cells. This experiment led to the discovery that cell migration is the primary response of injured epithelia. Collective cell migration caused mechanical stretch that provided stimuli for cell proliferations to repair the injured tubule. In order to determine the time when the pronephric tubule of zebrafish acquire the ability of regeneration, Yakulov et al., (2018) used a 2 photon laser to ablate a small part of pronephric tubules in $\mathrm{Tg}(\mathrm{c} / \mathrm{dn} 2 \mathrm{~b}$ :lyn-GFP) embryos at different time points and followed the regeneration process. They found that the ablation of pronephric tubules of 2-day old embryos was rapidly repaired by migratory responses, whereas 1 day old embryos did not have this ability. They carried out gene expression profiling of injured zebrafish embryos and found that $c x c r 4 b$ and myca are involved in this repair process (Yakulov et al., 2018).

\section{Chemical genetics}

Small bioactive molecules can be used to interfere with protein function and understand their biological role. A large number of chemical libraries are commercially available or can be custommade for probing protein function. These small molecule libraries include kinase inhibitors, protease inhibitors, nuclear receptors and ligands that can be used to identify the role of signaling pathways involved in organ development and function (Kawasumi and Nghiem, 2007). In the last few decades, zebrafish has emerged as a powerful vertebrate model organism for high-throughput chemical screening and phenotypic scoring (Kaufman et al., 2009). Cao et al., (2009) used the chemical screen approach to identify compounds that can reverse phenotypes caused by mutations in pkd2 (causal gene of PKD) and ift172 (a gene responsible for cilia formation). They uncovered that a pan-histone deacetylase (pan-HDAC) inhibitor trichostatin A (TSA) and a class-I specific HDAC inhibitor valproic acid (VPA) can suppress kidney cyst formation in pkd2knock-out model (Cao et al., 2009). Thus, chemical genetics can be a useful tool to identify new drug candidates that can either reverse or suppress disease conditions. 


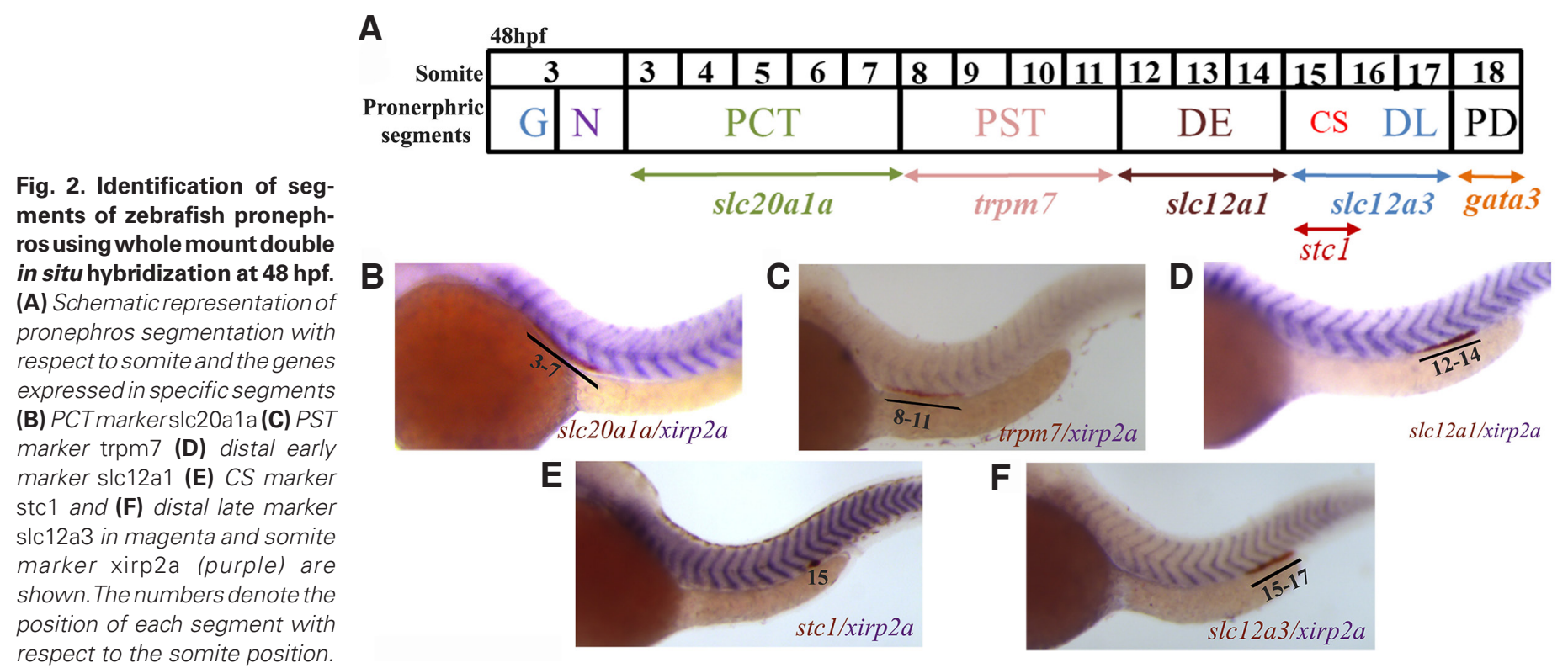

\section{Genetically inducible kidney injury models}

A genetically inducible tissue ablation model can be used in zebrafish in which bacterial nitroreductase (NTR) is expressed under the control of a promoter of choice that drives expression of NTR in a particular segment of pronephros. NTR converts metronidazole into a cytotoxic metabolite that can cause death to NTR expressing cells (Curado et al., 2008). Zhou and Hildebrandt (2012) used this technique to induce injury of podocyte by expressing NTR under the control of podocin promoter in Tg(pod:NTR-mCherry) zebrafish line. They also developed a double transgenic line of VDBP-GFP (Vitamin D binding protein tagged with GFP) as a tracer of proteinuria along with $T g$ (pod:NTR-mCherry) line. Treatment with metronidazole caused injury of podocyte resulting in whole body edema and accumulation of VDBP-GFP in proximal tubules, mimicking the phenotype of the human nephrotic syndrome (Zhou and Hildebrandt, 2012).

\section{Methods to evaluate pronephros development and function in zebrafish}

We have described the methods to generate human kidney disease models by using zebrafish. The creation of a disease model using another organism is the initial step, which needs to be evaluated for its ability to faithfully recapitulate various aspects of a disease seen in humans. Zebrafish offers many advantages that can be used to quickly evaluate its ability to serve as a surrogate to understand human kidney diseases as discussed below.

\section{Morphology based screening}

Most often mutant zebrafish embryos show morphological differences, compared with the wild-type that can be easily judged by observations under the microscope. The transparency of zebrafish embryos and their ability to survive up to 5 days even with severe developmental defects is a major advantage in morphology-based screens. Common morphological changes observed in zebrafish embryos with defective pronephros include pericardial edema, pronephric cysts, curved body axis and hydrocephalus (Poureetezadi and Wingert, 2016; Outtandy et al., 2019). Edema is one of the common signs of a defective kidney which is also seen in other organ deficiencies such as heart development (Hanke et al., 2013). Mutants with kidney defects may develop cysts because of over-proliferation of epithelial cells, as can be easily observed under a microscope (Zhao and Malicki, 2007; Yamaguchi et al., 2006). Curved body axis is often seen in mutants having pronephric cilia defects. Mutant zebrafish such as locke (lok), shen yan ${ }^{\text {t2114}} a$ (shy), garbus $^{t m 304}$ (grb) and zatortge38a (zar) are some of the examples showing curved body axis (Zhao and Malicki, 2007). Zebrafish mutants with kidney defects show multiple morphological defects in the same embryo. The knock-down of two polycystin genes $p k d 1 a$ and $p k d 1 b$ led to dorsally curved body axis, hydrocephaly, cartilage and craniofacial defects with low frequency of pronephric cysts (Mangos et al., 2010). The mutants of intraflagellar transport proteins ift57, ift88 and ift172, where cilia were defective, had ventrally curved body axis (Lunt et al., 2009). Thus, the zebrafish mutants with defective kidney exhibit many morphological features that can be easily identified.

\section{Histological analysis}

The mutants may not always show sufficiently informative morphological changes. Histological analysis of these embryos or organs of the adults may be necessary to determine the difference between the mutant and wild-type animals. Histological analysis methods for both larvae and adult zebrafish are well established and can be performed in a high throughput manner (Sabaliauskas et al., 2006). Zebrafish embryos or adult tissue can be embedded in paraffin or JB-4 resin followed by microtome sectioning to study tissue architecture (Sullivan-Brown et al., 2011; Copper et al., 2018). Cryo-sectioning can also be performed with zebrafish embryos (Ferguson and Shive, 2019). These tissue sections are then used for immunofluorescence staining, immuno histochemical studies or H\&E staining. H\&E staining of adult kidney sections showed that the apical side of proximal tubule was stained dark pink and had a wide lumen, while the distal tubule had light pink 
stain with narrow lumen, thus clearly marking the differential staining pattern between the segments (McCampbell et al., 2015). The periodic acid-Schiff (PAS) staining technique which detects polysaccharides in tissues has affinity for brush border epithelium of proximal tubule (McCampbell et al., 2015; McKee and Wingert, 2015). Methenamine silver stains the basement membranes and can be used for nephric tubules and glomeruli basement membrane staining (McCampbell et al., 2015). An AKI model of zebrafish by gentamicin insult showed flattening of epithelium, loss of apical brush border, tubular distention and accumulation of debris in lumen, thus highlighting the usefulness of histology in analyzing zebrafish disease models (Cianciolo Cosentino et al., 2013).

\section{Identification of pronephros segmentation defects}

The pronephros is patterned into different segments that perform distinct functions. The mechanism behind this segmentation is not clearly understood, although many transcription factors have been identified as regulators of segmentation. The differences in segmental pattern can easily be identified by WISH analysis with riboprobes that specifically mark different segments of the pronephros. The exact position of the pronephros segments can be marked by implementing double in situ hybridization of segment specific markers and an antisense riboprobe that marks the somite (such as smyhc1 and xirp2a). Most common segment specific markers are slc20a1a for PCT, trpm7 for PST, slc12a1 for DE, stc1 for CS and slc12a3 for DL (Fig. 2). Mutations in human HNF1 $\beta$ are linked with renal abnormalities like renal dysplasia, glomerulocycstic kidney, oligomeganephronia and solitary functioning kidney (Lindner, 1999; Bingham et al., 2002; Bohn et al., 2003). Naylor et al., (2013) analysed pronephros segmentation by WISH in hnf1b knock-out zebrafish embryos using segment specific marker genes and found that proximal and distal tubule markers were absent in the mutants. Using similar experiments, it was found that transcription factor empty spiracles homeobox gene 1 (emx1) promotes distal late fate and inhibits distal early fate during nephrogenesis (Morales et al., 2018). Wingert et al., (2007) carried out WISH analysis of RA and DEAB treated embryos and found that DEAB treatment resulted in a loss of the proximal segments and an expansion of the distal segments, while exogenous RA treatment reversed this phenotype. They also established a link between caudal transcription factor $(\mathrm{cdx})$ and $\mathrm{RA}$ in regulating nephron position and segmentation (Wingert et al., 2007). We have shown that the EF-hand domain containing 2 (efhc2) knockdown results in expansion of distal early segments and reduction in CS and distal late segment. The expression of odf3, which marks multiciliated cells of pronephric tubules, was also reduced in efhc2 morphants (Barrodia et al., 2018).

\section{Pronephric cilia staining and imaging}

Cilia are microtubule-based organelles that are either motile or non-motile. Human disorders caused due to defects in cilia structure and function are called ciliopathies. Defects in cilia present in zebrafish pronephros often lead to body curling, cyst formation and tubule dilation (Sullivan-Brown et al., 2008). Multiciliated cells present in zebrafish pronephros can be visualized by WISH or fluorescence in situ hybridization (FISH) using antisense odf3b or $r f x 2$ riboprobes (Liu et al., 2007; Barrodia et al., 2018). Cilia in zebrafish embryos can be stained using $\alpha$-acetylated tubulin and $\gamma$-tubulin can be used to mark the basal bodies (Jaffe et al., 2010; Zaghloul and Katsanis 2011). Movement of motile cilia can be recorded using a microscope with a high speed camera by employing transgenic zebrafish such as $\mathrm{Tg}$ (Foxj1a:GFP) (Tavares et al., 2017). A combined technique of FISH and immune fluorescence assay was developed to mark multiciliated cells, cilia and basal bodies (Marra et al., 2017). Different zebrafish mutants with cilia defects such as locke, swt and kurly were examined in detail and it was found that they showed a range of cilia movement defects (Sullivan-Brown et al., 2008). The ciliary motion was reduced in locke mutant and cilia were immotile in swt, whereas cilia movements in kurlyranged from motionless to irregular shifts. Immunostaining with $\alpha$-acetylated tubulin showed that the length of cilia was normal in swt and kurly whereas locke displayed shorter cilia (Sullivan-Brown et al., 2008). The methods described here have been used extensively to identify cilia defects in kidney diseases involving cilia.

\section{Evaluation of glomerulus function}

The main functions of the kidney is to filter blood and remove wastes and excess fluids from the body while preventing the loss of macromolecules into the urine. The glomerulus can filter out molecules of $5 \mathrm{kDa}$ but do not allow excretion of larger molecules such as serum albumin (Chang et al., 1976). Diagnostic methods commonly used to evaluate kidney dysfunction in humans cannot be applied to zebrafish because of its small size. However, fluorescent dyes of different molecular weights mimicking the molecules commonly encountered by the human kidney can be injected into zebrafish, and the assessment of their clearance or retention can be used as a surrogate to determine kidney function (Christou-Savina et al., 2015). It has been proven that the injection of $10 \mathrm{kDa}$ fluorescent dextran into the pericardial cavity of zebrafish embryos results in a loss of about $85 \%$ of dye through secretion from the kidney within 24 hours post-injection (hpi) (Christou-Savina et al., 2015). Dyes of higher molecular weight such as $70 \mathrm{kDa}$ or above need injection into vasculature and are retained within in wild-type embryos. However, 70 kDa dextran could be detected in the proximal tubule wall when injected into the vasculature of cystinosis (ctns) mutant zebrafish, indicating that the integrity of glomerulus filter slits is compromised in ctns $^{-/}$- larvae (Elmonem et al., 2017). Kramer-Zucker et al., (2005) injected 500 kDa FITCdextran into the cardinal vein of $84 \mathrm{hpf}$ wild-type and nephrin and podocin morphant zebrafish embryos, and detected the dye in the pronephros indicating dysfunction of nephrons in these morphants.

\section{Evaluation of reabsorption of metabolites}

Transmembrane endocytic receptor megalin/LRP2, its adaptor disabled2 (dab2) and coreceptor cubilin play a central role in endocytosis mediated clearance of metabolites from glomerular filtrate (Anzenberger, 2006). The injection of $70 \mathrm{kDa}$ fluorescently labelled dextran or fluorescently conjugated receptor-associated protein (RAP), a protein that physically associates with megalin/ LRP2 in bloodstream of zebrafish embryos, leads to uptake of these molecules for reabsorption. This serves as a convenient method for evaluating the metabolite reabsorption function of the kidney. In agreement with their central role in the reabsorption of metabolites, the knock-down of either megalin/LRP2 or dab2 
leads to a complete failure of receptor mediated endocytic uptake of tracers in morphants (Anzenberger, 2006).

\section{Assessment of tubule dilation}

The pronephric tubule is lined by a single layer of polarized epithelial cells. The morphology of pronephric tubule and its patterning into distinct segments are controlled by the proliferation of differentiated epithelial cells near the distal end and their migration towards the glomerulus. These events are in turn governed by the fluid flowing in the pronephros, thus providing a correlation between organ morphology and function (Vasilyev et al., 2009). The cells at the proximal end are convoluted and more columnar in shape, whereas the cells at the distal end are cuboidal (Vasilyev et al., 2009). A decrease in glomerular filtration rate, obstruction in tubule or defects in cilia development and motility inhibit this collective cell migration from posterior to anterior direction. However, cells at the distal end continue to proliferate, causing the dilation of pronephric tubules (Naylor and Davidson, 2017). Tubule dilation can be assessed either by directly observing whole embryos under microscope or histological analysis. DIC optics can be used to image and calculate the diameter of pronephric tubule of zebrafish embryos. Sullivan-Brown etal., (2008) compared the tubule dilation in wild-type and kurly mutants having defects in cilia, and found that in the wild-type the medial tubule had larger diameter compared with the posterior tubule, and that the diameter of medial tubules decreased over time. In kurly mutants the diameter of the medial and posterior tubules was similar to the wild-type at 26-30 hpf, but a constant increase in medial tubule diameter was observed in these mutants at $48 \mathrm{hpf}$ onwards. It was further observed that the number of cells surrounding the medial tubule also increased in mutant embryos (Sullivan-Brown et al., 2008). Mutations in the human MNX1 (motor neuron and pancreas homeobox 1) gene cause Currarino syndrome, a rare congenital disease characterized by sacral agenesis and urogenital and renal abnormalities such as horseshoe kidney, single kidney, hydronephrosis and anorectal stenosis (Currarino et al., 1981; Lee et al., 2018; Dworschak et al., 2021). Ott et al., (2016) generated $m n x 2 b$ morphants in a $T g(-8 c l d n b .1: l y n E G F P)^{z f 106}$ background to image epithelia cells in developing pronephros, and found that the morphants showed enlarged proximal tubule diameters as compared with wild-type controls at $4 \mathrm{dpf}$. Further analysis revealed that these morphants had altered kidney functions, disorganized pronephric cilia and deformed apical microvilli (Ott et al., 2016). Such analysis using zebrafish would undoubtedly help us to understand the underlying mechanism of human diseases.

\section{Assessment of epithelial cells polarity}

The epithelial cells polarity of the pronephric tubule is maintained by protein complexes that segregate the cellular membrane into apical and basolateral domains, and organize membrane subdomains for specific functions like secretion, filtration, absorption and sensory stimulation (Pieczynski and Margolis, 2011). The dislocation of a number of receptors, transporters and channels has been identified in many disease conditions like $\mathrm{Na}^{+} \mathrm{K}^{+}-\mathrm{ATPase}$, $\mathrm{Na}^{+} \mathrm{K}^{+} 2 \mathrm{Cl}^{-}$cotransporter and EGFR in PKD and $\mathrm{H}^{+}$-ATPase in Dent's disease (Wilson, 2011). The polarity of epithelial cells can be checked by immunofluorescence staining of whole embryos using antibody against $\mathrm{Na}^{+} / \mathrm{K}^{+}$-ATPase, tight junction marker $\mathrm{ZO}-1$ or alkaline phosphatase (AP) to identify the defects in polarization of tubule epithelia in mutants compared with wild-type embryos. $\mathrm{Na}^{+} / \mathrm{K}^{+}$-ATPase is one of the most abundant proteins in tubular epithelial cells which maintains sodium-potassium homeostasis and regulates the functions of other transporters present in epithelial cells (Fernández and Malnic, 1998). It is localized to the basolateral plasma membrane and is important for epithelial cell polarization and the formation and maintenance of tight junctions (Rajasekaran et al., 2001). ZO-1 and AP are used to mark the apical surfaces of the pronephric epithelial cells. Drummond et al., (1998) analyzed a group of mutants having mild to severe defect in pronephros. They checked the polarity of epithelial cells in $2.5 \mathrm{dpf}$ embryos by immunofluorescence staining with anti- $\mathrm{Na}^{+} / \mathrm{K}^{+}$-ATPase alpha subunit monoclonal antibody $(\alpha 6 \mathrm{~F})$ followed by tissue sectioning. This analysis showed that $\mathrm{Na}^{+} / \mathrm{K}^{+}$-ATPase localization was altered in most of the mutant lines compared to its normal basolateral expression. In double bubble $(d b b)$ and fleer ( $f l$ l) mutants, the $\mathrm{Na}^{+} /$ $\mathrm{K}^{+}$-ATPase was expressed in the apical surface while basolateral surface showed reduced staining. Other mutants had more lateral staining, with unstained apical and basolateral surfaces (Drummond et al., 1998).

\section{Kidney stone detection}

Kidney stones are crystals of deposited salts, among which calcium stones are the most common (Evan, 2010). These are composed of calcium oxalate $(\mathrm{CaOx})$ and calcium phosphate $(\mathrm{CaP})$ in different ratios. Calcium stones can be expected in zebrafish mutants having altered calcium homeostasis. Vital dyes such as Alizarin red (red fluorescent) and Calcein (green fluorescent) can be used to detect calcium-containing tissues and kidney stones in zebrafish larvae. Elizondo et al., (2010) showed that 57 - 97\% of trpm 7 homozygous mutant embryos developed kidney stones at $5 \mathrm{dpf}$, whereas only $0-1.4 \%$ of wild-type siblings developed such stones. Imaging of alizarin red-stained trpm 7 homozygous mutant embryos at different time points showed that 2-4 dpf embryos had no stones, and the stones were observed at $5 \mathrm{dpf}$ in the lumen and not in the epithelium of pronephric tubule (Elizondo et al., 2010).

\section{Conclusions and future prospects}

The incidence of kidney diseases is rising at an alarming rate worldwide. There is an urgent need to identify the causes of these diseases and develop novel methods for their diagnosis and cure. The mammalian metanephric kidney is complex, making it difficult to understand the kidney disease pathology. The pronephros in zebrafish larvae is functional and has only two nephrons on either side of notochord with a shared glomerulus at the anterior and a cloaca at the posterior end. In this review, we have discussed various methods that can be used to generate zebrafish models of human kidney diseases and how to analyse the phenotype of these disease models at morphological, cellular and molecular level. Painstaking research by many groups have established these methods of disease model generation and analysis over the years. These efforts have now established that the zebrafish embryos and adults can be used as human kidney disease models that can faithfully recapitulate various aspects of kidney dysfunction seen in humans. These efforts have also generated many useful tools 
and resources, including mutant and transgenic lines. This offers an opportunity not only to understand kidney disease mechanisms using zebrafish, but to use them to discover new drugs for treating kidney diseases. Diabetes is a major contributor to kidney related complications in humans. Zebrafish offers an opportunity where the diabetes-related kidney dysfunction can also be studied (Jörgens et al., 2012). Thus, zebrafish has an excellent foundation as a disease model and offers enormous potential to find novel solutions to human diseases.

\section{Acknowledgements}

We thank Tarique Anwar and Supriya Borah for their discussions and comments. SF is a recipient of DBT (DBT/2015/ILS/361) and UR is a recipient of the DST-Inspire fellowship. Research in RKS laboratory is supported by SERB-EMR (EMR/2016/003780) and intramural funds from the ILS, which is an autonomous institute of DBT, Government of India.

\section{Author contribution}

SF conceived and wrote the first manuscript. UN and RKS discussed and modified the manuscript.

\section{References}

AMSTERDAM A, BURGESS S, GOLLING G, CHEN W, SUN Z, TOWNSEND K, FARRINGTON S, HALDI M, HOPKINS N (1999). A large-scale insertional mutagenesis screen in zebrafish. Genes Dev 13: 2713-2724.

ANZENBERGER U (2006). Elucidation of megalin/LRP2-dependent endocytic transport processes in the larval zebrafish pronephros. J Cell Sci 119: 2127-2137.

BARRODIA P, PATRA C, SWAIN RK (2018). EF-hand domain containing 2 (Efhc2) is crucial for distal segmentation of pronephros in zebrafish. Cell Biosci 8: 53.

BEGEMANN G, SCHILLING TF, RAUCH G-J, GEISLER R, INGHAM PW (2001). The zebrafish neckless mutation reveals a requirement for raldh2 in mesodermal signals that pattern the hindbrain. Development 128: 3081-3094.

BIKBOV B, PURCELL CA, LEVEY AS, SMITH M, ABDOLI A, ABEBE M, ADEBAYO OM, AFARIDEH M, AGARWALSK, AGUDELO-BOTERO M, et al., (2020). Global, regional, and national burden of chronic kidney disease, 1990-2017: a systematic analysis for the Global Burden of Disease Study 2017. Lancet 395: 709-733.

BILL BR, PETZOLD AM, CLARK KJ, SCHIMMENTI LA, EKKER SC (2009). A primer for morpholino use in zebrafish. Zebrafish 6: 69-77.

BINGHAM C, ELLARD S, COLE TRP, JONES KE, ALLEN LIS, GOODSHIP JA, GOODSHIPTHJ, BAKALINOVA-PUGHD, RUSSELLGI, WOOLFAS, NICHOLLS AJ, HATTERSLEY AT (2002). Solitary functioning kidney and diverse genital tract malformations associated with hepatocyte nuclear factor- $1 \beta$ mutations. Kidney Int 61: 1243-1251.

BOCH J, BONAS U (2010). Xanthomonas AvrBs3 Family-Type III Effectors: Discovery and Function. Annu Rev Phytopathol 48: 419-436.

BOHN S, THOMAS H, TURAN G, ELLARD S, BINGHAM C, HATTERSLEY AT, RYFFEL GU (2003). Distinct Molecular and Morphogenetic Properties of Mutations in the Human HNF1 $\beta$ Gene That Lead to Defective Kidney Development. $J$ Am Soc Nephrol 14: 2033-2041.

CANTAGREL V, SILHAVY JL, BIELAS SL, SWISTUN D, MARSH SE, BERTRAND JY, AUDOLLENT S, ATTIÉ-BITACH T, HOLDEN KR, DOBYNS WB, et al., (2008). Mutations in the Cilia Gene ARL13B Lead to the Classical Form of Joubert Syndrome. Am J Hum Genet 83: 170-179.

CAO Y, SEMANCHIK N, LEE SH, SOMLO S, BARBANO PE, COIFMAN R, SUN Z (2009). Chemical modifier screen identifies HDAC inhibitors as suppressors of PKD models. Proc Natl Acad Sci 106: 21819-21824.

CARNEY EF (2020). The impact of chronic kidney disease on global health. Nat Rev Nephrol 16: 251-251.

CHAMBERS BE, WINGERT RA (2016). Renal progenitors: Roles in kidney disease and regeneration. World $J$ Stem Cells 8: 367-375.

CHANG RLS, DEEN WM, ROBERTSON CR, BENNETT CM, GLASSOCK RJ, BRENNER BM, TROY JL, UEKI IF, RASMUSSEN B (1976). Permselectivity of the glomerular capillary wall. Studies of experimental glomerulonephritis in the rat using neutral dextran. J Clin Invest 57: 1272-1286.

CHRISTOU-SAVINA S, BEALES PL, OSBORN DPS (2015). Evaluation of Zebrafish Kidney Function Using a Fluorescent Clearance Assay. J Vis Exp 96: e52540.

CIANCIOLO COSENTINO C, ROMAN BL, DRUMMOND IA, HUKRIEDE NA (2010). Intravenous Microinjections of Zebrafish Larvae to Study Acute Kidney Injury. J Vis Exp 42: e2079.

CIANCIOLO COSENTINO C, SKRYPNYK NI, BRILLI LL, CHIBA T, NOVITSKAYAT, WOODS C, WEST J, KOROTCHENKO VN, MCDERMOTT L, DAY BW, DAVIDSON AJ, HARRIS RC, DE CAESTECKER MP, HUKRIEDE NA (2013). Histone Deacetylase Inhibitor Enhances Recovery after AKI. JAm Soc Nephrol24:943-953.

COPPER JE, BUDGEON LR, FOUTZ CA, VAN ROSSUM DB, VANSELOW DJ, HUBLEY MJ, CLARK DP, MANDRELL DT, CHENG KC (2018). Comparative analysis of fixation and embedding techniques for optimized histological preparation of zebrafish. Comp Biochem Physiol Part C Toxicol Pharmacol 208: 38-46.

CREWS DC, BELLO AK, SAADI G (2019). Burden, access and disparities in kidney disease. Rev Nefrol Dial y Trasp/ 39: 1-11.

CURADO S, STAINIER DYR, ANDERSON RM (2008). Nitroreductase-mediated cell/ tissue ablation in zebrafish: a spatially and temporally controlled ablation method with applications in developmental and regeneration studies. NatProtoc 3: 948-954.

CURRARINO G, COLN D, VOTTELER T (1981). Triad of anorectal, sacral, and presacral anomalies. Am J Roentgenol 137: 395-398.

DESGRANGEA, CEREGHINIS (2015). Nephron Patterning: Lessons from Xenopus, Zebrafish, and Mouse Studies. Cells 4: 483-499.

DIEP CQ, MAD, DEO RC, HOLM TM, NAYLOR RW, ARORAN, WINGERT RA, BOLLIG F, DJORDJEVIC G, LICHMAN B, ZHU H, IKENAGA T, ONO F, ENGLERT C, COWAN CA, HUKRIEDE NA, HANDIN RI, DAVIDSON AJ (2011). Identification of adult nephron progenitors capable of kidney regeneration in zebrafish. Nature 470: 95-100.

DIEP CQ, PENG Z, UKAH TK, KELLY PM, DAIGLE R V., DAVIDSON AJ (2015). Development of the zebrafish mesonephros. genesis 53: 257-269.

DRUMMOND I (2003). Making a zebrafish kidney: a tale of two tubes. Trends Cell Biol 13: 357-365.

DRUMMOND IA, MAJUMDAR A, HENTSCHEL H, ELGER M, SOLNICA-KREZEL L, SCHIER AF, NEUHAUSS SCF, STEMPLE DL, ZWARTKRUIS F, RANGINI Z, DRIEVER W, FISHMAN MC (1998). Early development of the zebrafish pronephros and analysis of mutations affecting pronephric function. Development 125: 4655-4667.

DWORSCHAK GC, REUTTERHM, LUDWIGM (2021). Currarino syndrome: a comprehensive genetic review of a rare congenital disorder. Orphanet J Rare Dis 16: 167

EISEN JS, SMITH JC (2008). Controlling morpholino experiments: don't stop making antisense. Development 135: 1735-1743.

EL-BROLOSY MA, STAINIER DYR (2017). Genetic compensation: A phenomenon in search of mechanisms Ed. C Moens. PLOS Genet 13: e1006780.

ELIZONDO MR, BUDI EH, PARICHY DM (2010). Trpm7 Regulation of in vivo Cation Homeostasis and Kidney Function Involves Stanniocalcin 1 and Fgf23. Endocrinology 151: 5700-5709.

ELMONEM M, BERLINGERIO S, VAN DEN HEUVEL L, DE WITTE P, LOWE M,

LEVTCHENKO E (2018). Genetic Renal Diseases: The Emerging Role of Zebrafish Models. Cells 7: 130

ELMONEM MA, KHALIL R, KHODAPARAST L, KHODAPARAST L, ARCOLINO FO, MORGAN J, PASTORE A, TYLZANOWSKI P, NY A, LOWE M, DE WITTE PA, BAELDE HJ, VAN DEN HEUVEL LP, LEVTCHENKO E (2017). Cystinosis (ctns) zebrafish mutant shows pronephric glomerular and tubular dysfunction. Sci Rep 7: 42583.

ENE-IORDACHE B, PERICO N, BIKBOV B, CARMINATI S, REMUZZI A, PERNAA, ISLAM N, BRAVO RF, ALECKOVIC-HALILOVIC M, ZOU H, et al., (2016). Chronic kidney disease and cardiovascular risk in six regions of the world (ISN-KDDC): a cross-sectional study. Lancet Glob Heal 4: e307-e319.

EVAN AP (2010). Physiopathology and etiology of stone formation in the kidney and the urinary tract. Pediatr Nephrol 25: 831-841.

FERGUSON JL, SHIVE HR (2019). Sequential Immunofluorescence and Immunohistochemistry on Cryosectioned Zebrafish Embryos. J Vis Exp 147: e59344.

FERNÁNDEZ R, MALNIC G (1998). H + ATPase and Cl - Interaction in Regulation of MDCK Cell pH. J Membr Biol 163: 137-145. 
FOREMANKJ, MARQUEZN, DOLGERTA, FUKUTAKIK, FULLMANN, MCGAUGHEY M, PLETCHER MA, SMITH AE, TANG K, YUAN C-W, et al., (2018). Forecasting life expectancy, years of life lost, and all-cause and cause-specific mortality for 250 causes of death: reference and alternative scenarios for 2016-40 for 195 countries and territories. Lancet 392: 2052-2090.

GELDSETZER P, MANNE-GOEHLER J, THEILMANN M, DAVIES JI, AWASTHI A, VOLLMER S, JAACKS LM, BÄRNIGHAUSEN T, ATUN R (2018). Diabetes and Hypertension in India. JAMA Intern Med 178: 363.

HANKE N, STAGGS L, SCHRODER P, LITTERAL J, FLEIG S, KAUFELD J, PAULI C, HALLER H, SCHIFFER M (2013). "Zebrafishing" for Novel Genes Relevant to the Glomerular Filtration Barrier. Biomed Res Int 2013: 1-12.

HELLMAN NE, LIU Y, MERKEL E, AUSTIN C, LE CORRE S, BEIER DR, SUN Z, SHARMAN, YODER BK, DRUMMOND IA (2010). The zebrafish foxj1a transcription factor regulates cilia function in response to injury and epithelial stretch. Proc Natl Acad Sci U S A 107: 18499-18504

HENTSCHELDM, PARK KM, CILENTIL, ZERVOSAS, DRUMMOND I, BONVENTRE $J$ V. (2005). Acute renal failure in zebrafish: a novel system to study a complex disease. Am J Physiol Physiol 288: F923-F929.

HILL NR, FATOBA ST, OKE JL, HIRST JA, O'CALLAGHAN CA, LASSERSON DS, HOBBS FDR (2016). Global Prevalence of Chronic Kidney Disease-ASystematic Review and Meta-Analysis Ed. G Remuzzi. PLoS One 11: e0158765.

HOWE K, CLARK MD, TORROJA CF, TORRANCE J, BERTHELOT C, MUFFATO M, COLLINS JE, HUMPHRAY S, MCLAREN K, MATTHEWS L, et al., (2013). The zebrafish reference genome sequence and its relationship to the human genome. Nature 496: 498-503.

JAFFE KM, THIBERGE SY, BISHER ME, BURDINE RD (2010). Imaging Cilia in Zebrafish. In Methods in Cell Biology (Ed. Cassimeris L, Tran P). Vol.97. Academic Press, pp. 415-435.

JAIN S (2014). Kidney Development and Related Anomalies. In Pathobiology of Human Disease Elsevier, pp. 2701-2715.

JHA V, GARCIA-GARCIA G, ISEKI K, LI Z, NAICKER S, PLATTNER B, SARAN R, WANG AYM, YANG CW (2013). Chronic kidney disease: Global dimension and perspectives. Lancet 382: 260-272.

JOBST-SCHWAN T, HOOGSTRATEN CA, KOLVENBACH CM, SCHMIDT JM, KOLB A, EDDY K, SCHNEIDER R, ASHRAF S, WIDMEIER E, MAJMUNDAR AJ, HILDEBRANDT F (2019). Corticosteroid treatment exacerbates nephrotic syndrome in a zebrafish model of magi2a knockout. Kidney Int 95: 1079-1090.

JOHNSONCS, HOLZEMERNF, WINGERTRA(2011). Laser Ablation of the Zebrafish Pronephros to Study Renal Epithelial Regeneration. J Vis Exp 54: 2845.

JÖRGENS K, HILLEBRANDS J-L, HAMMES H-P, KROLL J (2012). Zebrafish: A Model for Understanding Diabetic Complications. Exp Clin Endocrinol Diabetes 120: 186-187.

KAMEI CN, LIU Y, DRUMMOND IA (2015). Kidney Regeneration in Adult Zebrafish by Gentamicin Induced Injury. J Vis Exp 102: e51912.

KAUFMAN CK, WHITE RM, ZON L (2009). Chemical genetic screening in the zebrafish embryo. Nat Protoc 4: 1422-1432.

KAWASUMI M, NGHIEM P (2007). Chemical Genetics: Elucidating Biological Systems with Small-Molecule Compounds. J Invest Dermatol 127: 1577-1584.

KIM BH, ZHANG GJ (2020). Generating stable knockout zebrafish lines by deleting large chromosomal fragments using multiple gRNAs. G3 Genes, Genomes, Genet 10: 1029-1037.

KRAMER-ZUCKER AG (2005). Cilia-driven fluid flow in the zebrafish pronephros, brain and Kupffer's vesicle is required for normal organogenesis. Development 132: 1907-1921.

KRAMER-ZUCKER AG, WIESSNER S, JENSEN AM, DRUMMOND IA (2005). Organization of the pronephric filtration apparatus in zebrafish requires Nephrin, Podocin and the FERM domain protein Mosaic eyes. Dev Biol 285: 316-329.

KRISHNAMURTHY VG (1976). Cytophysiology of Corpuscles of Stannius. Int Rev Cytol 46: 177-249.

KROEGER PT, DRUMMOND BE, MICELI R, MCKERNAN M, GERLACH GF, MARRAAN, FOXA, MCCAMPBELL KK, LESHCHINERI, RODRIGUEZ-MARI A, BREMILLER R, THUMMEL R, DAVIDSON AJ, POSTLETHWAIT J, GOESSLING W, WINGERT RA (2017). The zebrafish kidney mutant zeppelin reveals that brca2/fancd1 is essential for pronephros development. Dev Biol 428: 148-163.

LAWSON ND, WOLFE SA (2011). Forward and Reverse Genetic Approaches for the Analysis of Vertebrate Development in the Zebrafish. Dev Cell 21: 48-64.
LEE S, KIM EJ, CHO SI, PARK H, SEO SH, SEONG M-W, PARK SS, JUNG S-E, LEE S-C, PARK K-W, KIM H-Y (2018). Spectrum of MNX1 Pathogenic Variants and Associated Clinical Features in Korean Patients with Currarino Syndrome. Ann Lab Med 38: 242-248.

LEVEY AS, ASTOR BC, STEVENS LA, CORESH J (2010). Chronic kidney disease, diabetes, and hypertension: What's in a name. Kidney Int 78: 19-22.

LINDNER TH, NJOLSTAD PR, HORIKAWA Y, BOSTAD L, BELL GI, SOVIK O (1999). A novel syndrome of diabetes mellitus, renal dysfunction and genital malformation associated with a partial deletion of the pseudo-POU domain of hepatocyte nuclear factor-1beta. Hum Mol Genet 8: 2001-2008.

LIU K, PETREE C, REQUENA T, VARSHNEY P, VARSHNEY GK (2019). Expanding the CRISPR Toolbox in Zebrafish for Studying Development and Disease. Front Cell Dev Biol 7: 13.

LIU Y, LUO D, LEI Y, HU W, ZHAO H, CHENG CHK (2014). A highly effective TALEN-mediated approach for targeted gene disruption in Xenopus tropicalis and zebrafish. Methods 69: 58-66.

LIU Y, PATHAK N, KRAMER-ZUCKER A, DRUMMOND IA (2007). Notch signaling controls the differentiation of transporting epithelia and multiciliated cells in the zebrafish pronephros. Development 134: 1111-1122.

LUNT SC, HAYNES T, PERKINS BD (2009). Zebrafish ift57, ift88, and ift172 intraflagellar transport mutants disrupt cilia but do not affect hedgehog signaling. Dev Dyn 238: 1744-1759.

MANGOS S, LAM P y., ZHAO A, LIU Y, MUDUMANA S, VASILYEV A, LIU A, DRUMMOND IA (2010). The ADPKD genes pkd1a/b and pkd2 regulate extracellular matrix formation. Dis Model Mech 3: 354-365.

MARRAAN, ULRICH M, WHITE A, SPRINGER M, WINGERT RA (2017). Visualizing Multiciliated Cells in the Zebrafish Through a Combined Protocol of Whole Mount Fluorescent In situ Hybridization and Immunofluorescence. J Vis Exp 129: 56261

MCCAMPBELLKK, SPRINGERKN, WINGERTRA(2015). Atlas of Cellular Dynamics during Zebrafish Adult Kidney Regeneration. Stem Cells Int 2015: 1-19.

MCKEE RA, WINGERT RA (2015). Zebrafish Renal Pathology: Emerging Models of Acute Kidney Injury. Curr Pathobiol Rep 3: 171-181.

MINGEOT-LECLERCQ MP, TULKENS PM (1999). Aminoglycosides : Nephrotoxicity Antimicrob Agents Chemother 43(5): 1003-1012.

MORALES EE, HANDA N, DRUMMOND BE, CHAMBERS JM, MARRA AN, ADDIEGO A, WINGERT RA (2018). Homeogene emx1 is required for nephron distal segment development in zebrafish. Sci Rep 8: 18038.

MULLINS MC, HAMMERSCHMIDT M, HAFFTERP, NÜSSLEIN-VOLHARD C (1994). Large-scale mutagenesis in the zebrafish: in search of genes controlling development in a vertebrate. Curr Biol 4: 189-202.

NAYLOR RW, CHANG H-HG, QUBISI S, DAVIDSON AJ (2018). A novel mechanism of gland formation in zebrafish involving transdifferentiation of renal epithelial cells and live cell extrusion. Elife 7: e38911.

NAYLOR RW, DAVIDSON AJ (2017). Pronephric tubule formation in zebrafish morphogenesis and migration. Pediatr Nephrol 32: 211-216.

NAYLOR RW, PRZEPIORSKI A, REN Q, YU J, DAVIDSON AJ (2013). HNF1 ßIs Essential for Nephron Segmentation during Nephrogenesis. J Am Soc Nephrol 24: 77-87.

OTT E, WENDIK B, SRIVASTAVA M, PACHO F, TÖCHTERLE S, SALVENMOSER W, MEYER D (2016). Pronephric tubule morphogenesis in zebrafish depends on Mnx mediated repression of irx1b within the intermediate mesoderm. Dev Biol 411: 101-114.

OUTTANDY P, RUSSELL C, KLETA R, BOCKENHAUER D (2019). Zebrafish as a model for kidney function and disease. Pediatr Nephrol 34: 751-762.

PALMYREA, LEE J, RYKLIN G, CAMARATAT, SELIG MK, DUCHEMINA-L, NOWAK P, ARNAOUTMA, DRUMMOND IA, VASILYEVA (2014). Collective Epithelial Migration Drives Kidney Repair after Acute Injury Ed. AJ Kabla. PLoS One 9: e101304.

PATTON EE, ZON LI (2001). The art and design of genetic screens: zebrafish. Nat Rev Genet 2: 956-966.

PIECZYNSKI J, MARGOLIS B (2011). Protein complexes that control renal epithelial polarity. Am J Physiol Physiol 300: F589-F601.

POUREETEZADI SJ, WINGERT RA(2016). Little fish, big catch: zebrafish as a model for kidney disease. Kidney Int 89: 1204-1210.

RAJAPURKAR MM, JOHN GT, KIRPALANI AL, ABRAHAM G, AGARWAL SK, ALMEIDAAF, GANG S, GUPTAA, MODI G, PAHARI D, PISHARODY R, PRAKASH 
J, RAMAN A, RANA DS, SHARMA RK, SAHOO R, SAKHUJA V, TATAPUDI RR, JHA V (2012). What do we know about chronic kidney disease in India: first report of the Indian CKD registry. BMC Nephrol 13: 10.

RAJASEKARAN SA, PALMER LG, MOON SY, PERALTA SOLER A, APODACA GL, HARPER JF, ZHENG Y, RAJASEKARAN AK (2001). Na,K-ATPase Activity Is Required for Formation of Tight Junctions, Desmosomes, and Induction of Polarity in Epithelial Cells Ed. G Guidotti. Mol Biol Cell 12: 3717-3732.

ROBERTS RJ, ELLIS AE (2012). The Anatomy and Physiology of Teleosts. In Fish Pathol Fourth Ed (Ed. Roberts RJ) Wiley, pp. 17-61.

ROBU ME, LARSON JD, NASEVICIUS A, BEIRAGHI S, BRENNER C, FARBER SA, EKKER SC (2007). p53 Activation by Knockdown Technologies Ed. M Mullins. PLoS Genet 3: e78.

ROSSIA, KONTARAKIS Z, GERRI C, NOLTE H, HÖLPER S, KRÜGER M, STAINIER DYR (2015). Genetic compensation induced by deleterious mutations but not gene knockdowns. Nature 524: 230-233.

SABALIAUSKAS NA, FOUTZ CA, MEST JR, BUDGEON LR, SIDOR AT, GERSHENSON JA, JOSHI SB, CHENG KC (2006). High-throughput zebrafish histology. Methods 39: 246-254.

SERTORI R, TRENGOVE M, BASHEER F, WARD AC, LIONGUE C (2016). Genome editing in zebrafish: a practical overview. Brief Funct Genomics 15: 322-330.

SHAH AN, DAVEY CF, WHITEBIRCH AC, MILLER AC, MOENS CB (2016). Rapid Reverse Genetic Screening Using CRISPR in Zebrafish. Zebrafish 13: 152-153.

SHAO W, ZHONG D, JIANG H, HAN Y, YIN Y, LI R, QIAN X, CHEN D, JING L (2020). A new aminoglycoside etimicin shows low nephrotoxicity and ototoxicity in zebrafish embryos. J Appl Toxicol 41:1063-1075.

SHARMA KR, HECKLER K, STOLL SJ, HILLEBRANDS J-L, KYNAST K, HERPEL E, PORUBSKYS, ELGERM, HADASCHIKB, BIEBACKK, HAMMESH-P, NAWROTH PP, KROLL J (2016). ELMO1 protects renal structure and ultrafiltration in kidney development and under diabetic conditions. Sci Rep 6: 37172.

SMYTH IM, CULLEN-MCEWEN LA, CARUANA G, BLACK MJ, BERTRAM JF (2017). Development of the Kidney. In Fetal and Neonatal Physiology Elsevier, pp. 953-964.e4

SULLIVAN-BROWN J, BISHER ME, BURDINE RD (2011). Embedding, serial sectioning and staining of zebrafish embryos using JB-4 resin. Nat Protoc 6: 46-55.

SULLIVAN-BROWN J, SCHOTTENFELD J, OKABE N, HOSTETTER CL, SERLUCA FC, THIBERGE SY, BURDINE RD (2008). Zebrafish mutations affecting cilia motility share similar cystic phenotypes and suggest a mechanism of cyst formation that differs from pkd2 morphants. Dev Biol 314: 261-275.

SUMMERTON J (1999). Morpholino antisense oligomers: the case for an RNase $\mathrm{H}$-independent structural type. Biochim Biophys Acta - Gene Struct Expr 1489: 141-158.

SUN, Z. AMSTERDAM, A. PAZOUR, G.J. COLE, D.G. MILLER SM (2004). A genetic screen in zebrafish identifies cilia genes as a principal cause of cystic kidney. Development 131: 4085-4093.

TAHARA T, OGAWA K, TANIGUCHI K (1993). Ontogeny of the Pronephros and Mesonephros in the South African Clawed Frog, Xenopus laevis Daudin, with Special Reference to the Appearance and Movement of the Renin-immunopositive Cells. Exp Anim 42: 601-610.

TALLAFUSSA, GIBSOND, MORCOSP, LIY, SEREDICKS, EISENJ, WASHBOURNE $P$ (2012). Turning gene function ON and OFF using sense and antisense photo- morpholinos in zebrafish. Development 139: 1691-1699.

TAVARES B, JACINTO R, SAMPAIO P, PESTANAS, PINTO A, VAZA, ROXO-ROSA M, GARDNER R, LOPES T, SCHILLING B, HENRY I, SAÚDE L, LOPES SS (2017). Notch/Her12 signalling modulates, motile/immotile cilia ratio downstream of Foxj1a in zebrafish left-right organizer. Elife 6: e25165.

THOMAS R, KANSO A, SEDOR JR (2008). Chronic Kidney Disease and Its Complications. Prim Care - Clin Off Pract 35: 329-344.

VARMA PP (2015). Prevalence of chronic kidney disease in India - Where are we heading? Indian J Nephrol 25: 133-135.

VARSHNEY GK, BURGESS SM (2014). Mutagenesis and phenotyping resources in zebrafish for studying development and human disease. Brief Funct Genom ics 13: 82-94.

VARSHNEY GK, CARRINGTON B, PEI W, BISHOP K, CHEN Z, FAN C, XU L, JONES M, LAFAVE MC, LEDIN J, SOOD R, BURGESS SM (2016). A high-throughput functional genomics workflow based on CRISPR/Cas9-mediated targeted mutagenesis in zebrafish. Nat Protoc 11: 2357-2375.

VARUGHESE S, ABRAHAM G (2018). Chronic Kidney Disease in India. Clin J Am Soc Nephrol 13: 802-804.

VASILYEV A, LIU Y, MUDUMANA S, MANGOS S, LAM P-Y, MAJUMDAR A, ZHAO J, POON K-L, KONDRYCHYN I, KORZH V, DRUMMOND IA (2009). Collective Cell Migration Drives Morphogenesis of the Kidney Nephron Ed. DL Stemple. PLOS Biol 7: e1000009.

VERLANDER JW (1998). Normal Renal Function and Alterations of Renal Function in States of Nephrotoxicity Normal Ultrastructure of the Kidney and Lower Urinary Tract. Toxicol Pathol 26: 1-17.

WILSON PD (2011). Apico-basal polarity in polycystic kidney disease epithelia Biochim Biophys Acta - Mol Basis Dis 1812: 1239-1248.

WINGERT RA, DAVIDSON AJ (2011). Zebrafish nephrogenesis involves dynamic spatiotemporal expression changes in renal progenitors and essential signals from retinoic acid and irx3b. Dev Dyn 240: 2011-2027.

WINGERT RA, SELLECK R, YU J, SONG HD, CHEN Z, SONG A, ZHOU Y, THISSE B, THISSE C, MCMAHON AP, DAVIDSON AJ (2007). The cdx genes and retinoic acid control the positioning and segmentation of the zebrafish pronephros. PLOS Genet 3: 1922-1938.

YAKULOVTA, TODKARAP, SLANCHEVK, WIEGELJ, BONAA, GROSS M, SCHOLZ A, HESS I, WURDITSCH A, GRAHAMMER F, et al., (2018). CXCL12 and MYC control energy metabolism to support adaptive responses after kidney injury. Nat Commun 9: 1-15.

YAMAGUCHI T, HEMPSON SJ, REIF GA, HEDGE A-M, WALLACE DP (2006) Calcium Restores a Normal Proliferation Phenotype in Human Polycystic Kidney Disease Epithelial Cells. J Am Soc Nephrol 17: 178-187.

ZAGHLOUL NA, KATSANIS N (2011). Zebrafish Assays of Ciliopathies. In Methods in Cell Biology (Ed. Detrich H.W., Westerfield M, Zon L. I). Vol. 105. Academic Press, pp. 257-272.

ZHAO C, MALICKI J (2007). enetic defects of pronephric cilia in zebrafish. Mech Dev 124: 605-616.

ZHOU W, DAI J, ATTANASIO M, HILDEBRANDTF (2010). Nephrocystin-3 is required for ciliary function in zebrafish embryos. Am J Physiol Physiol 299: F55-F62.

ZHOU W, HILDEBRANDT F (2012). Inducible podocyte injury and proteinuria in transgenic zebrafish. J Am Soc Nephrol 23: 1039-1047. 


\section{Further Related Reading, published previously in the Int. J. Dev. Biol.}

Zebrafish embryo, a tool to study tumor angiogenesis

Chiara Tobia, Giulia De Sena and Marco Presta

Int. J. Dev. Biol. (2011) 55: 505-509

https://doi.org/10.1387/ijdb.103238ct

\section{Hematopoietic development in the zebrafish}

Elizabeth J. Paik and Leonard I. Zon

Int. J. Dev. Biol. (2010) 54: 1127-1137

https://doi.org/10.1387/ijdb.093042ep

Linking wound response and inflammation to regeneration in the zebrafish larval fin Henry Hamilton Roehl

Int. J. Dev. Biol. (2018) 62: 473-477

https://doi.org/10.1387/ijdb.170331hr

Zebrafish development and regeneration: new tools for biomedical research

Sebastiaan A. Brittijn, Suzanne J. Duivesteijn, Mounia Belmamoune, Laura F.M.Bertens, Wilbert Bitter, Joost D. de Bruijn, Danielle L. Champagne, Edwin Cuppen, Gert Flik, Christina M. Vandenbroucke-Grauls et al.

Int. J. Dev. Biol. (2009) 53: 835-850

https://doi.org/10.1387/ijdb.082615sb

Rapid quantification of neutral lipids and triglycerides during zebrafish embryogenesis Prusothman Yoganantharjah, Avinesh R. Byreddy, Daniel Fraher, Munish Puri and Yann Gibert Int. J. Dev. Biol. (2017) 61: 105-111

https://doi.org/10.1387/ijdb.160209yg

\section{Developmental biology of zebrafish myeloid cells}

Meredith O Crowhurst, Judith E Layton and Graham J Lieschke

Int. J. Dev. Biol. (2002) 46: 483-492

http://www.intjdevbiol.com/web/paper/12141435
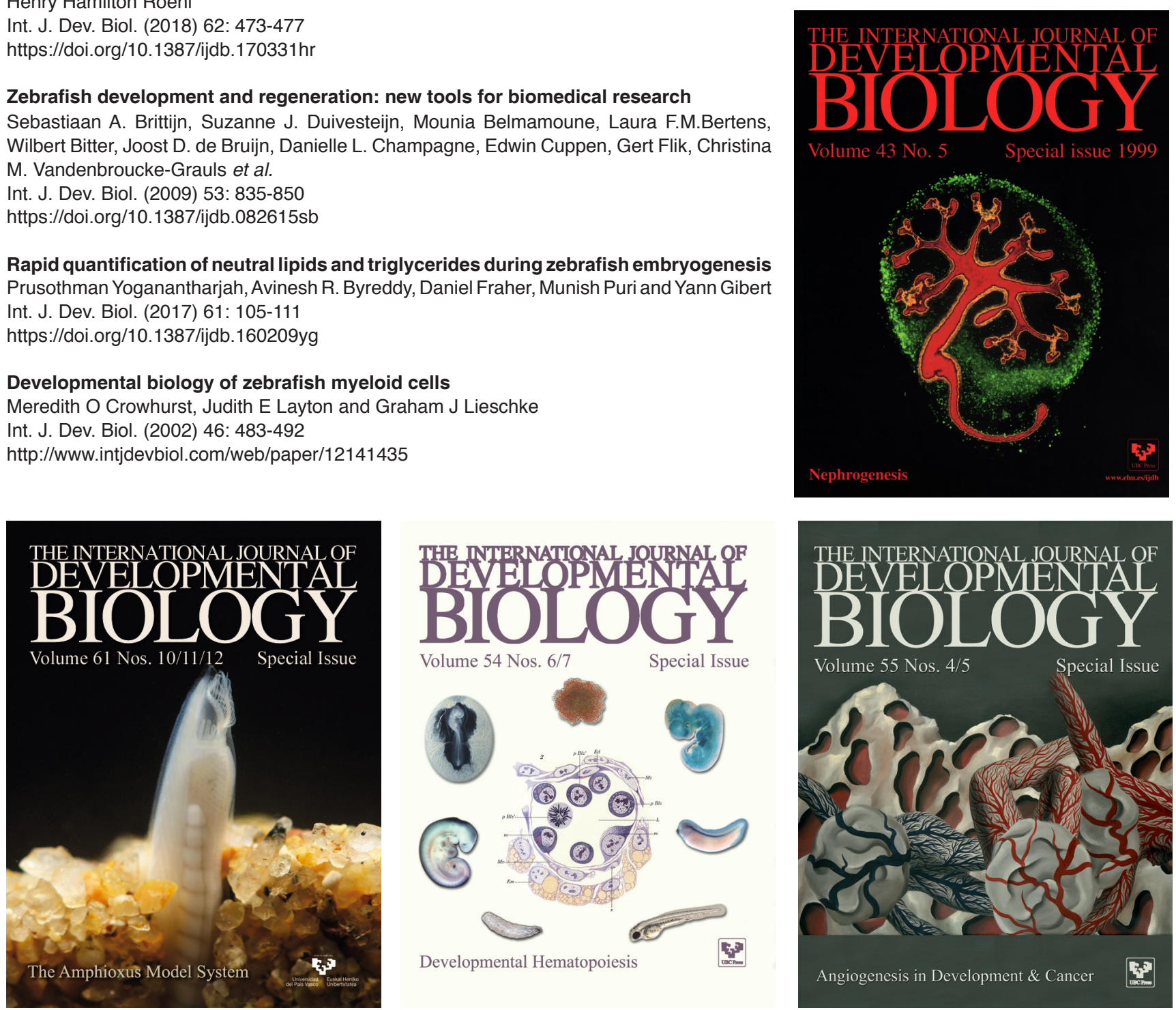

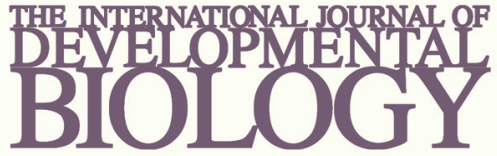

Volume 54 Nos. $6 / 7$

Special Issue
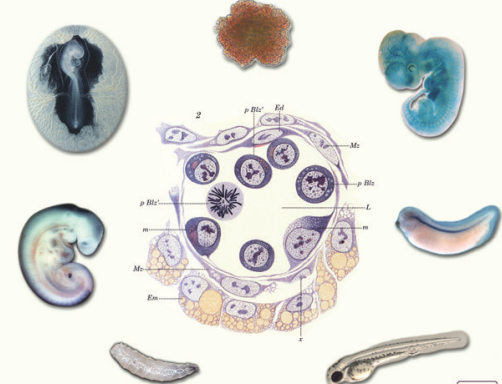

Developmental Hematopoiesis

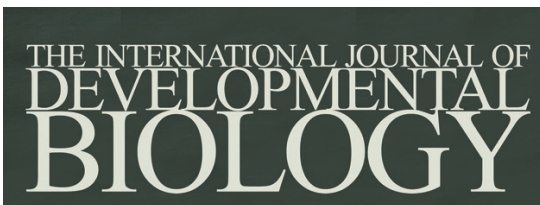

Volume 55 Nos. $4 / 5$

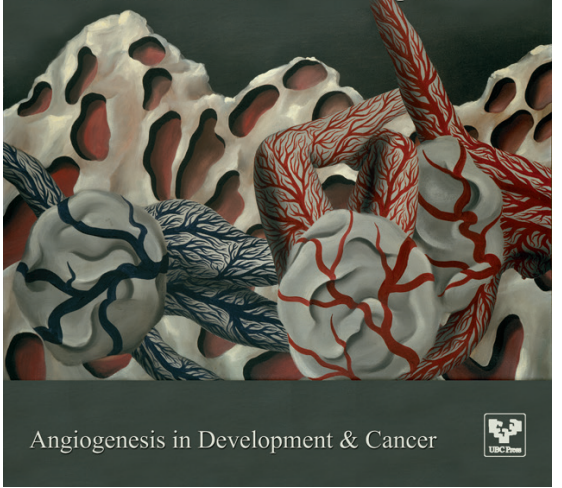

